\title{
Morphology and significance of transverse ridges (De Geer moraines) adjacent to the Moray Firth, NE Scotland.
}

\author{
Andrew Finlayson*, Tom Bradwell, Nick Golledge, Jon Merritt \\ British Geological Survey, Murchison House, West Mains Road, Edinburgh, EH9 3LA \\ * Corresponding author. E-mail: afin@bgs.ac.uk
}

\begin{abstract}
High-resolution NEXTMap digital surface models and aerial photographs are used to map suites of transverse ridges at Tarbat Ness and to the west of Elgin, along the margins of the Moray Firth in north-east Scotland. Based on their morphology, configuration and location, we interpret these landforms as De Geer moraines which formed at or near former grounding line positions of the Moray Firth palaeo-ice stream. The Tarbat Ness De Geer moraines almost certainly formed at a marine margin. Reaching altitudes of 55 $\mathrm{m}$ above present $\mathrm{OD}$, these landforms may provide one of the highest geomorphological indicators for former relative sea level in mainland Britain. Evidence from surrounding landforms and sediments suggest that the ridges formed between c. 15,000-18,000 cal yrs BP, indicating that a significant fall in relative sea level may have taken place prior to an ice margin readvance in the Moray Firth, known as the Ardersier Oscillation.
\end{abstract}

Key Words: Glacial landforms, DSMs, transverse ridges, De Geer moraines, sea level

\section{Introduction}

Landforms occupying coastal areas around the Moray Firth provide a wealth of evidence concerning glacier recession and sea-level change at the end of the last, Main Late Devensian (MLD) glaciation (e.g. Peacock et al., 1968; Firth, 1989; Merritt et al., 1995; Merritt et al., 2003). During that glaciation the north-east sector of the British Ice Sheet was drained by a major ice stream which occupied the Moray Firth, flowing rapidly over the underlying soft, deformable, muddy sea-bed and Mesozoic sedimentary rocks (Merritt 
et al., 2003). As ice in Scotland retreated, glacio-isostatic rebound failed at first to keep pace with the worldwide (eustatic) rise in sea level. Consequently, raised beaches and associated marine deposits are now found around the Moray Firth at altitudes up to $>30$ m above OD (Firth, 1989, 1990; Merritt et al., 1995). Isostatic uplift was greatest where the ice was thickest, with the result that raised beaches are tilted north-eastwards, away from a centre of uplift in the western Grampians (Firth, 1989).

Deglaciation of the Moray Firth is thought to have been punctuated by at least two significant ice margin oscillations (whereby ice retreat was interrupted by a readvance, followed by renewed retreat), at Elgin (Peacock et al., 1968) and Ardersier (Smith, 1966; Merritt et al., 1995), while a further stillstand occurred at Alturlie (Merritt et al., 1995) (Figure 1). The latter two events have been tentatively linked to short-lived accelerated periods of glacio-isostatic rebound and concomitant temporary falls in relative sea level, while the phases of ice retreat in between have been attributed to rapid calving and rising global sea level (Merritt et al., 1995).

New high-resolution digital surface models (DSMs) and 1:10,000 aerial photographs have enabled more detailed landform mapping of coastal fringes around the Moray Firth, providing the opportunity to build on existing models of deglaciation. The aim of this paper is to present morphological characteristics from two suites of transverse ridges that lie between the former ice-margin oscillation positions at Elgin and Ardersier (Figure 1). The origin for these landforms is discussed and wider implications for deglaciation and relative sea-level change are explored.

\section{Methods}

Landforms on the Tarbat Ness peninsula and around the Mosstowie Canal, to the west of Elgin, were mapped in a spatially attributed ESRI Arc GIS database using the NEXTMap DSM ( $5 \mathrm{~m} \times 5 \mathrm{~m}$ horizontal, $1.5 \mathrm{~m}$ vertical resolution) and georectified, monoscopic colour 1:10,000 aerial photographs. Manipulation in the GIS enabled the DSM to be illuminated from various azimuths limiting the bias introduced by relief-shading, while 
increasing vertical exaggeration allowed better visualisation of some landforms (c.f. Smith \& Clark, 2005). Geometric data derived from the DSM enabled detailed morphometric analysis to be performed on individual landforms.

Published 1:50,000 geological maps (Institute of Geological Sciences, 1969, 1972) were interrogated for existing landform data and to determine the Quaternary deposits which had been mapped in the area. Unpublished, larger scale clean copy maps held in the British Geological Survey (Edinburgh) archives were also examined.

\section{Results}

Two sets of broadly north-north-west to south-south-east trending transverse ridges occur in association with raised marine deposits on the Tarbat Ness peninsula (Figure 2), and around the Mosstowie Canal, to the west of Elgin (Figure 3).

The Tarbat Ness landforms lie inland of Devensian raised marine deposits and above former shorelines, at altitudes of c. $25-55 \mathrm{~m}$ OD. Lying in an area primarily composed of till, these linear ridges traverse across topographic undulations of up to $30 \mathrm{~m}$ and trend directly towards the Moray Firth (Figure 2, Figure 4A). They were originally mapped as 'long drumlins', or drumlins (Geological Survey of Scotland, 1913) and used by B.N. Peach to suggest a south-south-easterly former ice-flow direction from their alignment. The landforms are $<6 \mathrm{~m}$ high, $40-90 \mathrm{~m}$ wide and $140-1120 \mathrm{~m}$ long (Table 1). While ridge spacing ranges from $80-280 \mathrm{~m}$, it is relatively even for much of the area with a mean of spacing of $147 \mathrm{~m}$. Cross-profile analysis (measured perpendicular to ridge axes) of a selection of ridges reveals a generally symmetrical to slightly asymmetrical profile with a tendency for east-facing slopes to be steeper (Figure 5A). Occasionally, ridge crests bifurcate at their northern end, while a group of ridges to the north-east possess a slightly different alignment trending almost north-east to south-west.

The landforms to the west of Elgin are 3 - $7 \mathrm{~m}$ high, 50 - $90 \mathrm{~m}$ wide, $200-1220 \mathrm{~m}$ long and traverse across topographic undulations of up to $20 \mathrm{~m}$. The ridges are generally 
evenly spaced (mean spacing of $192 \mathrm{~m}$ ) with the exception of those to the east where the landforms are less frequent. They occur over an identical altitudinal range to the Tarbat Ness landforms (c. $25-55 \mathrm{~m}$ above OD), occupying low ground between topographic highs to the north and south. Cross-profile analysis reveals a largely consistent morphometry, with ridges being symmetrical or slightly asymmetrical, with steeper eastfacing slopes (Figure 5B). The landforms were identified previously by Peacock et al. (1968) as 'esker-like ridges', and lie on till, within a complex mapped as glaciofluvial sands and gravels and glaciolacustrine deposits (Institute of Geological Sciences, 1969).

\section{Interpretation}

Original mapping of the Tarbat Ness landforms as drumlins (Geological Survey of Scotland, 1913) is not consistent with regional ice-flow indicators, which show that ice flowed out of the Moray Firth towards the east (Merritt et al., 2003). Furthermore, the ridge dimensions (Table 1) are not typical of those generally reported for drumlins (Benn \& Evans, 1998).

Networks of narrow, sometimes cross-cutting, transverse ridges have been observed in the forelands of surging glaciers (e.g. Evans et al., 1999; Evans \& Rea 2005). These landforms, known as crevasse 'squeeze' or 'fill' ridges are believed to form as sediment is squeezed into basal crevasses in highly fractured glaciers following surges. Ridges tentatively interpreted as crevasse squeeze ridges have been identified at Dalcross, approximately $10 \mathrm{~km}$ to the north-east of Inverness (Fletcher et al., 1996; British Geological Survey, 1997). While the pattern of ridges described in the present study bear some similarity to crevasse squeeze ridges, there are considerable differences in scale. For example, Sharp (1985) described a suite of crevasse fill ridges at Eyjabakkajökull, Iceland, with widths of less than $10 \mathrm{~m}$. Similarly Kleman (1988) and Boulton et al. (1996) have reported crevasse squeeze ridges that were $4-14 \mathrm{~m}$ and $<20 \mathrm{~m}$ wide respectively, while Bennett et al. (2003) report widths of only $2-3 \mathrm{~m}$. The average widths of landforms at Tarbat Ness and Elgin are c. $50 \mathrm{~m}$ and c. $60 \mathrm{~m}$ respectively, suggesting that an alternative mechanism may have been responsible for their formation. 
Furthermore, other landforms indicative of glacier surging (e.g. flutings, thrust-block moraines) have not been observed in the study areas.

Suites of regularly spaced transverse ridges in formerly glaciated areas have also been interpreted as De Geer moraines (e.g. Larsen et al., 1991; Blake, 2000; Linden \& Möller, 2005; Todd et al., 2007). Originally described by De Geer (1889), and named after him by Hoppe (1959), De Geer moraines are low ridges, typically $<10 \mathrm{~m}$ high, $10-100 \mathrm{~m}$ wide, and $100-1000 \mathrm{~m}$ long (Golledge \& Phillips, in press). Aligned approximately transverse to ice flow, these landforms form in subaqueous environments at or near former ice margins. Zilliacus (1989) argued that these closely spaced, linear, moraines form in subglacial crevasses behind a calving glacier margin. However, more recent investigations have led to an alternative model where sediments are deposited or pushed up at the grounding line of a water-terminating glacier forming the transverse ridges (Larsen et al., 1991; Blake, 2000; Lindén \& Möller, 2005; Todd et al., 2007). The ridge dimensions described in the present study are similar to those reported for De Geer moraines elsewhere (Table 1), while the symmetrical to asymmetrical cross-profiles (with steeper distal slopes) have also been observed in other studies (e.g. Sollid, 1989; Blake, 2000; Linden \& Möller, 2005; Golledge \& Philips, in press). Todd et al. (2007) report De Geer moraines traversing bathymetric ranges of up to $25 \mathrm{~m}$. This characteristic is observed in the present study where individual ridges trend linearly across topographic undulations of up to $30 \mathrm{~m}$, suggesting formation at a steep, water-terminating ice front. Occurring in an area where relative sea level is known to have been at least c. $30 \mathrm{~m}$ higher than present following ice margin recession (Synge \& Smith, 1980; Firth, 1989; Merritt et al., 1995), we choose to interpret the landforms as De Geer moraines - the Tarbat Ness landforms marking successive former marine grounding line positions of the Moray Firth palaeo-ice stream as it retreated westwards. The bifurcations and subtle change in alignment at the north-eastern end of the Tarbat Ness suite of De Geer moraines may be due to convergence and interplay of ice that flowed into the Dornoch and Moray Firths (Figure 6). 
The De Geer moraines to the west of Elgin occur in association with sediments interpreted as glaciolacustrine (Peacock et al., 1968; Institute of Geological Sciences, 1969). The ice margin here may have terminated in a lake that was at least periodically dammed by ice that occupied the Moray Firth to the north. The presence of more extensive suites of lake sediments in the lower reaches of Strath Spey, also relating to ponding along the southern margin of the Moray Firth ice lobe, supports such a scenario (e.g. Peacock, 1968; Hall et al., 2004). However, it is interesting to note that the upper altitude of De Geer moraines at Elgin and Tarbat Ness is identical, suggesting that the maximum water surface altitude at both sites may have been similar.

\section{Discussion}

If a De Geer moraine interpretation is correct, as suggested by their morphology and configuration, the Tarbat Ness landforms would provide one of the highest geomorphological indicators for former relative sea level in mainland Britain. For that reason it is important to attempt to constrain their age. While no dates have yet been obtained for the formation of these features, surrounding deposits and landforms provide some clues.

Near Peterhead (Figure 1), a series of laminated dark grey silts, clays and fine sands, known as the St Fergus Silts Formation, occur onshore (Merritt et al, 2003). These raised marine deposits contain a shell bed from which two samples of Hiatella arctica have been dated at 14,915 \pm 205 and 14,345 $\pm 65{ }^{14} \mathrm{C}$ yrs BP (marine reservoir of $405 \mathrm{yrs}$ ) (Hall and Jarvis, 1989; Peacock, 1999) yielding a calibrated age range of approximately 18,150 - 16,200 cal yrs BP (Calib 5.3). In places, the silts are deformed and sheared, and lie within a push moraine feature (Hall \& Jarvis, 1989; Merritt et al., 2003). Deformation of these silts most probably occurred when the Moray Firth ice lobe terminated offshore beyond the north-eastern tip of Buchan, clearly predating formation of both sets of De Geer moraines to the west. 
Based on morphological observations and stratigraphic relationships, Peacock et al. (1968) concluded that during retreat of ice in the Moray Firth, a readvance took place at Elgin, causing ponding in the lower Spey Valley (Glacial Lake Fochabers) (Figure 6). Inside the limit of this 'Elgin Oscillation', fauna from proximal raised glaciomarine sediments around Lossiemouth, known as the Spynie Clay Formation (Merritt et al., 2003) have been correlated with the 'Errol Beds' of eastern Scotland (Peacock, 1999), broadly dated at $13,000-14,000{ }^{14} \mathrm{C}$ (approximately $15-17$ cal) years BP. The Spynie Clay Formation includes large dropstones and contains a till-like lens at the type section (Peacock, 1999), indicating the presence of a nearby ice-front. This locality is the westernmost limit of where fully arctic 'Errol Beds' fauna is known to occur, suggesting that the Elgin oscillation took place before warming commenced at c. 15,000 cal BP (Merritt et al., 1995). The De Geer moraines at Elgin and Tarbat Ness most likely formed shortly after that glacier oscillation.

A large push moraine together with overridden proglacial silts and sands indicate that a subsequent glacier oscillation occurred to the southwest at Ardersier (Smith, 1966; Merritt et al., 1995). Inside the limits of this feature, near Kessock (Figure 1), Lateglacial Interstadial and Loch Lomond Stadial sediments have been identified (Peacock \& Wilkinson, 1995). These younger deposits rest with erosional contacts upon sediments attributed to the Ardersier Oscillation, indicating that the oscillation clearly predated the onset of the Lateglacial Interstadial at c. 14,900 yrs BP. As they occur beyond the limits of the Ardersier Oscillation, both sets of De Geer moraines must therefore be older.

The above evidence suggests an age range of c. 18,000 - 15,000 cal yrs BP for the formation of the Moray Firth De Geer moraines, between the Elgin and Ardersier Oscillations (Figure 7). This range is before the time-span covered by published sealevel curves (Shennan et al., 2006) for the region. The maximum heights of the Tarbat Ness landforms (c. $55 \mathrm{~m}$ OD) suggest that relative sea level fell from altitudes higher than previously reported prior to the Ardersier Oscillation (Figure 7). Such a scenario is consistent with Merritt et al.'s (1995) suggestion that the Ardersier oscillation was caused by a fall in relative sea level. 
The remarkable preservation of the landforms presented in this study shows that they were not subjected to subsequent glacier overriding following formation. Their occurrence only above former high shorelines may indicate that a rapid fall in relative sea-level took place before open water coastal processes could erase the landforms. Presence of sea-ice throughout much of the year, consistent with Errol Beds conditions, could also have aided preservation by restricting coastal processes at that time.

\section{Conclusions}

New high-resolution DSMs and 1:10,000 aerial photographs have been used to map suites of transverse ridges at Tarbat Ness and to the west of Elgin along the margins of the Moray Firth. Based on their morphology, configuration and location, the ridges are interpreted as De Geer moraines marking successive former grounding line positions of the Moray Firth palaeo-ice stream. Although no dates have been directly obtained for the period of De Geer moraine formation, evidence from surrounding landforms and sediments suggests an age of between c. 15,000 - 18,000 cal years. The remarkable preservation of these features indicates that they were not subsequently overridden following formation or destroyed by open water coastal processes. Reaching altitudes of $55 \mathrm{~m} \mathrm{OD}$, these landforms suggest that a significant fall in relative sea-level took place prior to the Ardersier Oscillation. The Tarbat Ness De Geer moraines may provide valuable additional evidence for deciphering the history of relative sea level change in the Moray Firth area over the last c. 20,000 years.

\section{Acknowledgements}

This research was carried out as part of the BGS joint British Ice Sheet Reconstruction and Marine and Coastal Quaternary Mapping projects. Constructive comments from Clive Auton and Martyn Stoker improved earlier versions of this manuscript. Chris Stokes and an anonymous referee are thanked for their reviews. This paper is published with permission of the Executive Director of the British Geological Survey. 


\section{References}

Benn, D.I. \& Evans, D.J.A. 1998. Glaciers and Glaciation. Arnold, London.

Bennett, M.R., Waller, R., Midgley, N.G., Huddart, D., Gonzalez, S., Cook, S.J. \& Tomio, A. 2003. Subglacial deformation at sub-freezing temperatures? Evidence from Hagafellsjökull-Eystri, Iceland. Quaternary Science Reviews, 22, 915-923.

Blake, K.P. 2000. Common origin for De Geer moraines of variable composition in Raudvassdalen, northern Norway. Journal of Quaternary Science, 15, 633-644.

Boulton, G.S., Van Der Meer, J.J.M., Hart, J., Beets, D., Ruegg, G.H.J., Van Der Wateren, F.M. \& Jarvis, J. 1996. Till and moraine emplacement in a deforming bed surge - an example from a marine environment. Quaternary Science Reviews, 15, 961987.

British Geological Survey. 1997. Fortrose, Scotland Sheet 84W. 1:50,000. Keyworth, Nottingham

De Geer, G. 1889. Ändmoränerna i trakten mellan Spånga och Sundbyberg. Geologiska Föreningens i Stockholm Förhandlingar 11(126), 395-396.

Evans, D.J.A., Lemmen, D.S. \& Rea, B.R. 1999. Glacial landsystems of the southwest Laurentide Ice Sheet: modern Icelandic analogues. Journal of Quaternary Science, 14, 673-691.

Evans, D.J.A \& Rea, B.R. 2005. Surging glacier landsystem. In: D.J.A. Evans (ed), Glacial Landsystems. Arnold, London.

Firth, C.R. 1989. Late Devensian raised shorelines and ice limits in the inner Moray-Firth area, northern Scotland, Boreas 18, 5-21.

Firth, C.R. 1990. Late-Devensian relative sea-level changes associated with the deglaciation of the Inverness and Beauly Firths. In: Auton, C.A., Firth, C.R. and Merritt, J.W. (eds), Beauly to Nairn. Field Guide. Quaternary Research Association, Cambridge.

Fletcher, T.P., Auton, C.A., Highton, A.J., Merritt, J.W., Robertson, S. \& Rollin, K.E. 1996. Geology of the Fortrose and eastern Inverness district. British Geological Survey Memoir for Sheet 84, HMSO, London. 
Geological Survey of Scotland. 1913. Ross and Cromarty county sheet 43. Clean copy. HMSO.

Golledge, N.R. \& Phillips, E.R. in press. De Geer moraines in the western Scottish Highlands: sedimentological evidence and glaciodynamic implications. Sedimentary Geology.

Hall, A.M. \& Jarvis, J. 1989. A preliminary report on the late Devensian glaciomarine deposits around St. Fergus, Grampian Region, Quaternary Newsletter 59 5-7.

Hall, A.M., Jarvis, J. \& Connell, E.R., 2004. Glacial Lake Knockando and its bearing on the timing and sequence of the last deglaciation in Strath Spey, northeast Scotland. Quaternary Newsletter, 104, 52-54.

Hoppe, G. 1959. Glacial morphology and inland ice recession in northern Sweden. Geografiska Annaler 41, 193-212.

Institute of Geological Sciences. 1969. Elgin, Scotland Sheet 95. 1:50,000. Drift Edition. Nottingham.

Institute of Geological Sciences. 1972. Cromarty, Scotland Sheet 94. 1:50,000. Drift Edition. Nottingham.

Kleman, J. 1988. Linear till ridges in the southern Norwegian-Swedish mountains evidence for a subglacial origin. Geographiska Annaler, 70 A, 35-45.

Larsen, E., Longva, O. \& Follestad, B.A. 1991. Formation of De Geer moraines and implications for deglaciation dynamics. Journal of Quaternary Science, 6, 263-277.

Lindén, M., \& Möller, P. 2005. Marginal formation of De Geer moraines and their implications to the dynamics of grounding-line recession. Journal of Quaternary Science, $20,113-133$.

Merritt, J.W., Auton, C.A. \& Firth, C.R., 1995. Ice-proximal glaciomarine sedimentation and sea-level change in the Inverness area, Scotland - a review of the deglaciation of a major ice stream of the British late Devensian ice-sheet. Quaternary

Science Reviews, 14, 289-329.

Merritt, J.W., Auton, C.A., Connell, E.R., Hall, A.M. \& Peacock J.D. 2003. Late Cainozoic geology and landscape evolution of north-east Scotland. Memoir of the British Geological Survey, Sheets 66E, 67, 76E, 77, 86E, 87W, 87E, 95, 96W, 96E and 97 Scotland). British Geological Survey, Edinburgh.

Peacock, J.D. 1999. The Pre-Windermere Interstadial (Late Devensian) raised marine strata of eastern Scotland and their microfauna: a review. Quaternary Science Reviews, $18,1655-1680$. 
Peacock, J.D., Berridge, N.G., Harris, A.L. \& May, F. 1968. The geology of the Elgin district. Memoir of the Geological Survey of Scotland.

Peacock, J.D. \& Wilkinson, I.P. 1995. Appendix 1. Kessock Biostratigraphy. In Merritt, J.W., Auton, C.A., Firth, C.R., 1995. Ice-proximal glaciomarine sedimentation and sealevel change in the Inverness area, Scotland - a review of the deglaciation of a major ice stream of the British late Devensian ice-sheet. Quaternary Science Reviews, 14, 289329.

Sharp, M. 1985. "Crevasse-fill" ridges - a landform type characteristic of surging glaciers. Geografiska Annaler, 67 A, 213-220.

Shennan, I., Bradley, S., Milne, G., Brooks, A., Basset, S. \& Hamilton, S. 2006. Relative sea-level changes, glacial isostatic modeling and ice-sheet reconstructions from the British Isles since the Last Glacial Maximum. Journal of Quaternary Science, 21, $585-599$.

Smith, J.S. 1966. Morainic limits and their relationship to raised shorelines in the East Scottish Highlands. Transactions of the Institute of British Geographers, 39, 61-64.

Smith, M.J. \& Clark, C.D. 2005. Methods for the visualization of digital elevation models for landform mapping. Earth Surface Processes and Landforms, 30, 885-900.

Sollid, J. L. 1989. Comments on the genesis of De Geer moraines. Norsk Geografisk Tidsskrift,43, 45-47.

Synge, F.M. \& Smith, J.S. 1980. Inverness Field Guide. Quaternary Research Association, Cambridge.

Todd, B.J., Valentine, P.C., Longva, O. \& Shaw, J. 2007. Glacial landforms on the German Bank, Scotian Shelf: evidence for Late Wisconsinan ice-sheet dynamics and implications for the formation of De Geer moraines. Boreas, 36, 148-169.

Zilliacus, H. 1989. Genesis of De Geer moraines in Finland. Sedimentary Geology 62, 309-317. 


\section{Figure Captions}

Figure 1. The Moray Firth area in north-east Scotland. Boxes show locations of Figures 2 and 3 . Inset gives national context.

Figure 2. A. Geomorphological map of the Tarbat Ness area. Superficial geology simplified from Institute of Geological Sciences (1972). B. Hill-shaded digital surface model showing transverse ridges and raised shorelines on the Tarbat Ness peninsula. Surface model built from NEXTMap Britain topographic data. Illumination from the north-west.

Figure 3. A. Geomorphological map of the Mosstowie Canal area to the west of Elgin. Superficial geology simplified from Institute of Geological Sciences (1969). B. Hillshaded digital surface model showing transverse ridges around the Mosstowie Canal. Surface model built from NEXTMap Britain topographic data. Illumination from the north-west.

Figure 4. A. Oblique hill-shaded digital surface model showing transverse ridges on the Tarbat Ness peninsula. Vertical exaggeration x 5. Illumination from the west. B. Orthorectified monoscopic aerial photograph of transverse ridges on the Tarbat Ness Peninsula.

Figure 5. Cross profile data (perpendicular to ridge crests) for ridges at A: Tarbat Ness and B: Mosstowie Canal to the west of Elgin.

Figure 6. Tentative reconstruction of retreating Moray Firth ice front before, during and following De Geer moraine formation at Tarbat Ness and Elgin. 
Figure 7. Observations (sea-level index points) and model predictions for relative sealevel change in the Moray Firth area (from Shennan at al., 2006), together with altitude and suggested age of De Geer moraines and regional events in NE Scotland.

\section{Table Captions}

Table 1. Characteristic dimensions of ridges reported in this study and dimensions of De Geer moraines reported elsewhere. 


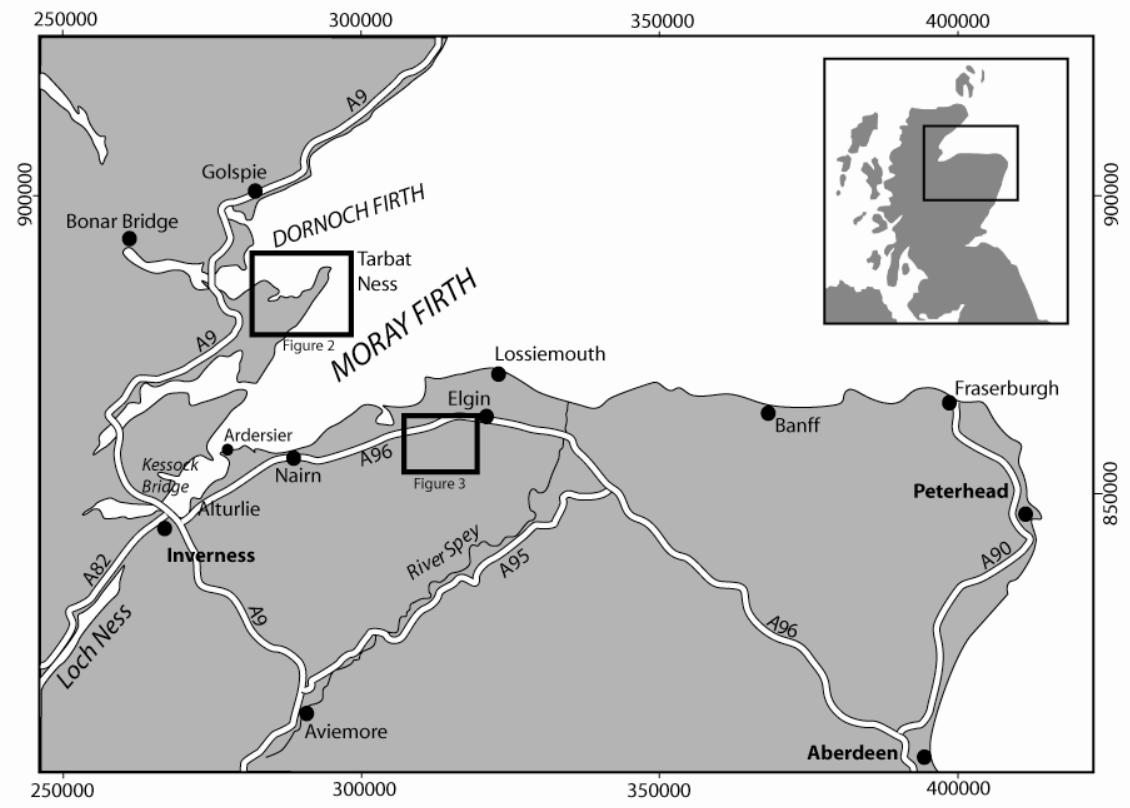

Figure 1. 

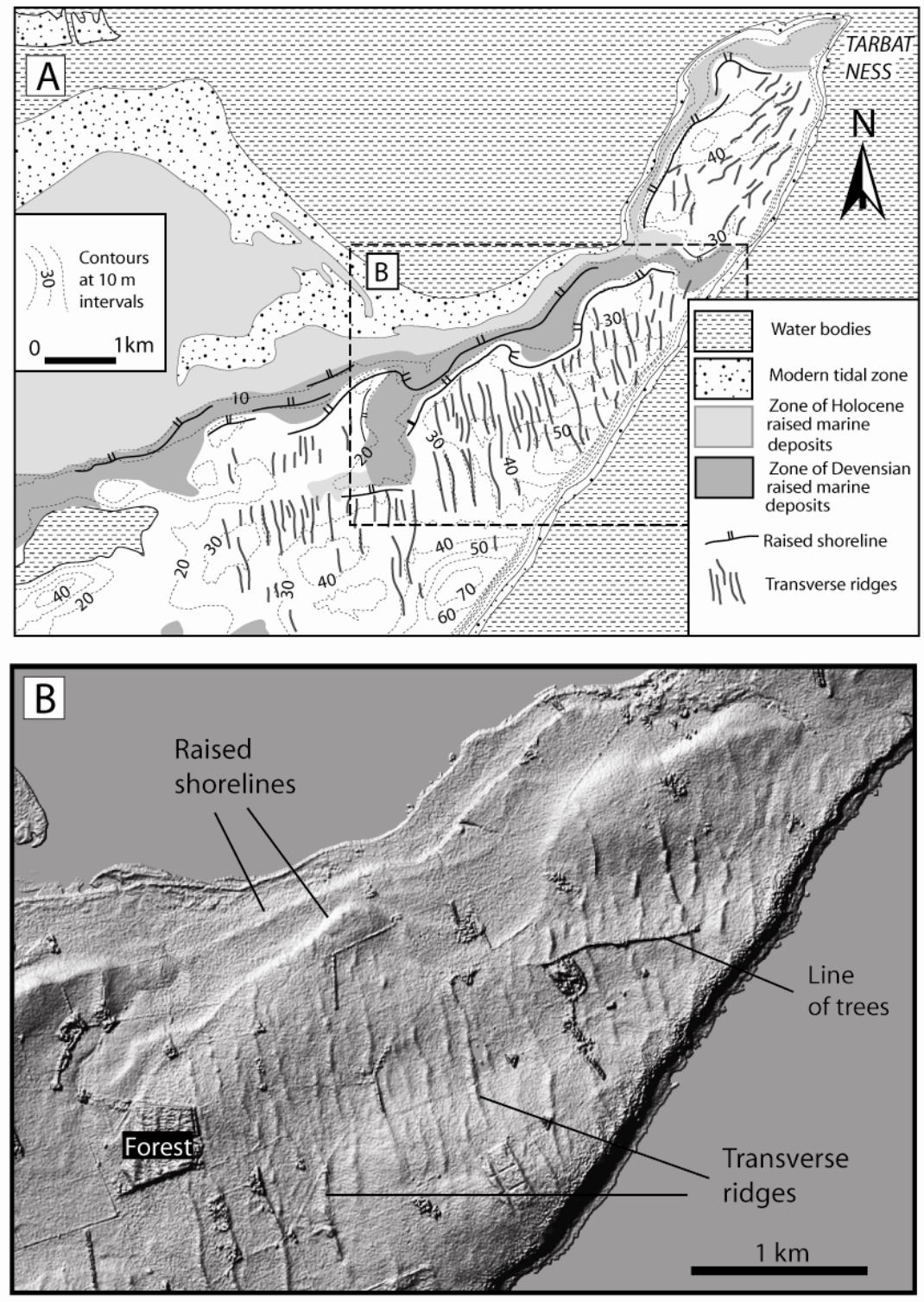

Figure 2. 

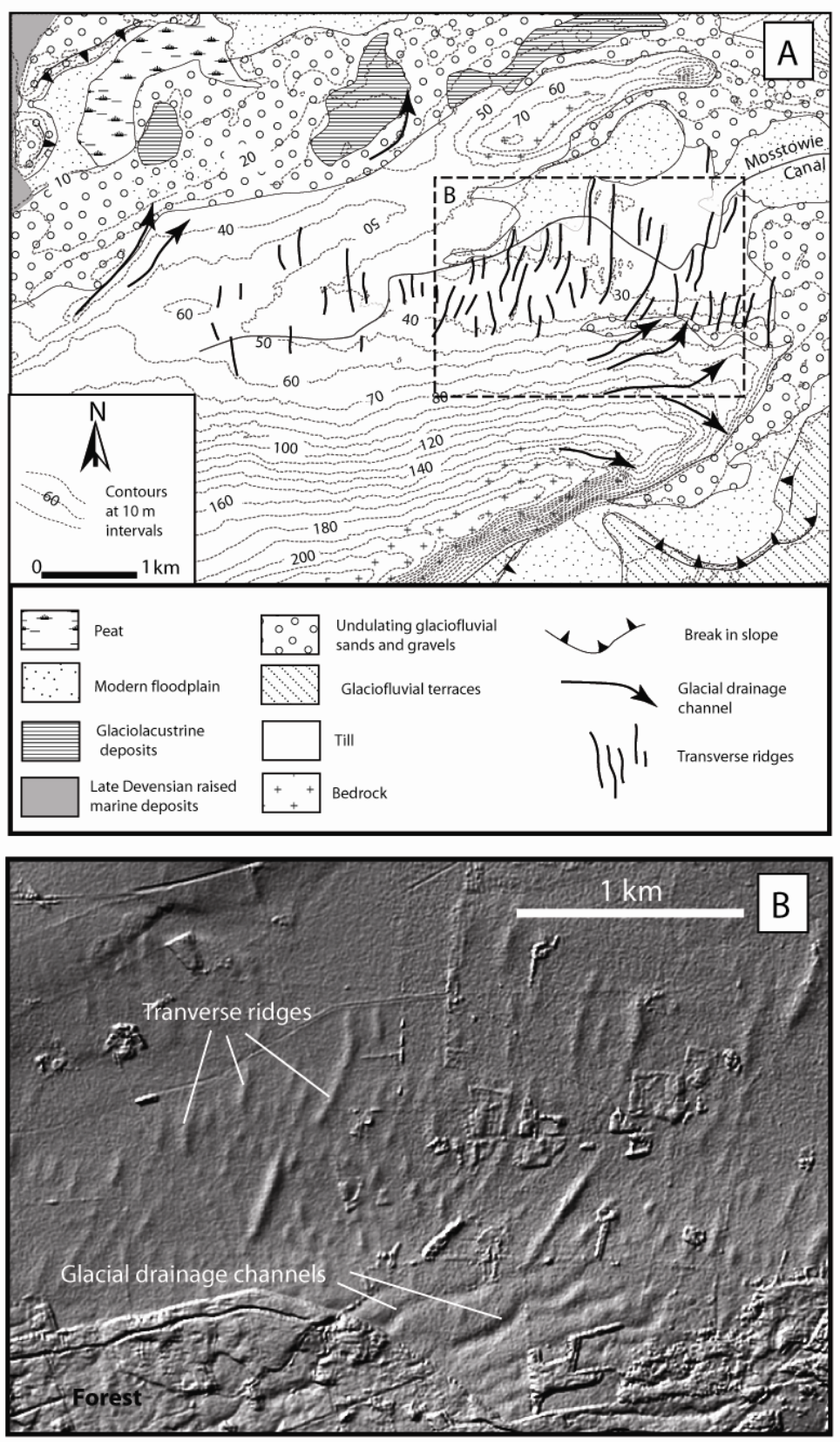

Figure 3. 

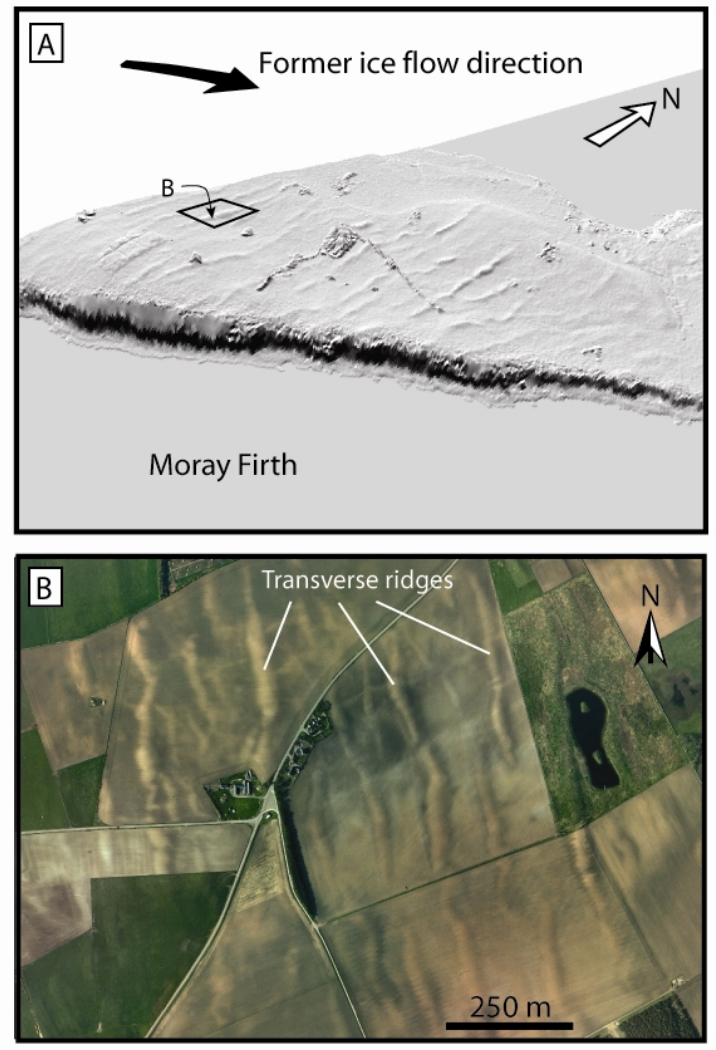

Figure 4. 
West
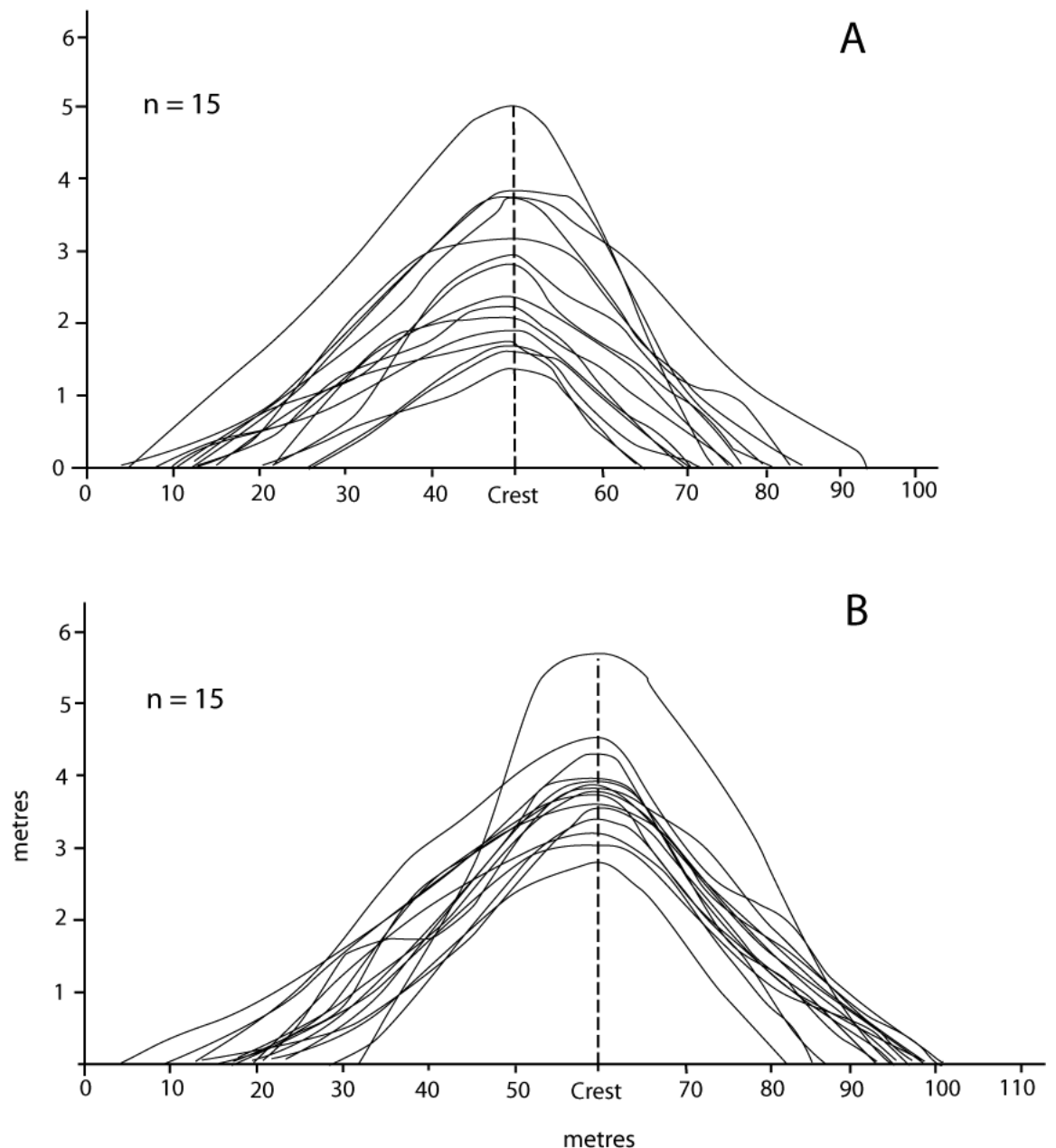

Figure 5. 


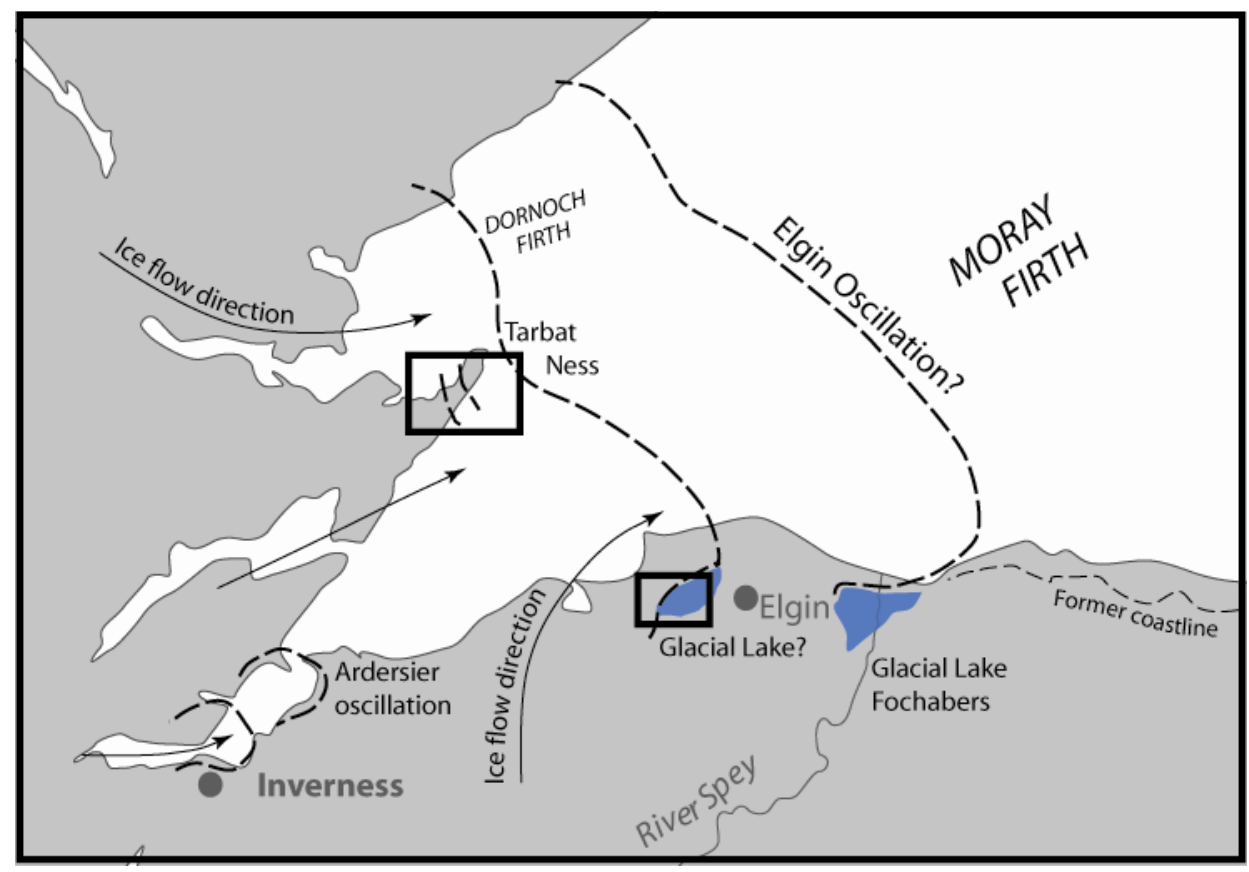

Figure 6. 


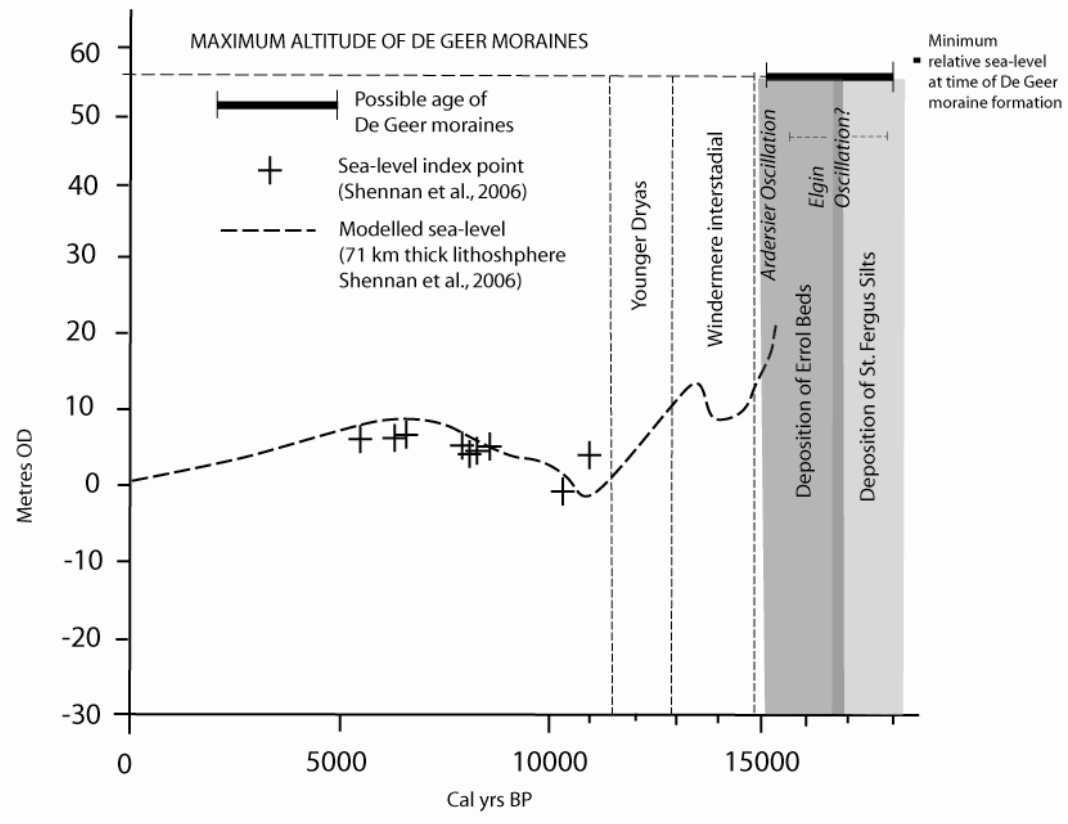

Figure 7. 


\begin{tabular}{|c|c|c|c|c|c|c|c|}
\hline \multirow{2}{*}{\begin{tabular}{c} 
Parameter \\
\cline { 2 - 8 }
\end{tabular}} & $\begin{array}{c}\text { Tarbat Ness } \\
(\mathrm{n}=20)\end{array}$ & $\begin{array}{c}\text { Elgin } \\
(\mathrm{n}=20)\end{array}$ & $\begin{array}{c}\text { Pasvik, } \\
\text { Norway }\end{array}$ & $\begin{array}{c}\text { More, } \\
\text { Norway }\end{array}$ & $\begin{array}{c}\text { Norbotten, } \\
\text { Sweden }\end{array}$ & $\begin{array}{c}\text { Scotian Shelf, } \\
\text { Nova Scotia }\end{array}$ & $\begin{array}{c}\text { Glen Chaorach, } \\
\text { Scotland }\end{array}$ \\
\hline $\begin{array}{c}\text { Height } \\
(m)\end{array}$ & $\begin{array}{c}1-5 \\
\text { mean. } 3\end{array}$ & $\begin{array}{c}3-7 \\
\text { mean: } 3\end{array}$ & $<10$ & $3-6$ & $1-3$ & $1.5-8$ & $<10$ \\
\hline $\begin{array}{c}\text { Width } \\
(m)\end{array}$ & $\begin{array}{c}42-89 \\
\text { mean: } 53\end{array}$ & $\begin{array}{c}47-92 \\
\text { mean: } 63\end{array}$ & 50 & $20-30$ & mean: 30 & $40-130$ & $20-35$ \\
\hline $\begin{array}{c}\text { Length } \\
(m)\end{array}$ & $\begin{array}{c}139-1120 \\
\text { mean: } 671\end{array}$ & $\begin{array}{c}196-1216 \\
\text { mean: } 497\end{array}$ & 1000 & $250-10000$ & $100-3000$ & $<10000$ & $50-100$ \\
\hline $\begin{array}{c}\text { Spacing } \\
(m)\end{array}$ & $\begin{array}{c}79-283 \\
\text { mean: } 147\end{array}$ & $\begin{array}{c}81-631 \\
\text { mean: } 192\end{array}$ & $10-100$ 's & $50-1200$ & $50-200$ & $30-200$ & $30-400$ \\
\hline $\begin{array}{c}\text { Reference } \\
\text { This study }\end{array}$ & This study & Sollid (1989) & $\begin{array}{c}\text { Larsen et al. } \\
(1991)\end{array}$ & $\begin{array}{c}\text { Linden and } \\
\text { Möller (2005) }\end{array}$ & $\begin{array}{c}\text { Todd et al. } \\
(2007)\end{array}$ & Ghillips (in press) \\
\hline
\end{tabular}

Table 1. 